\title{
O jornalismo e a nova cultura digital
}

JORNALISMO

PARA DISPOSITIVOS MÓVEIS

PRODUÇĀO.

DISTRIBUIÇĀO

E CONSUMO

\section{Marco Antonio Nogueira}

Mestrando no Programa de Comunicação da Universidade

Municipal de São Caetano do Sul.

4

E-mail: marco.nogueira@live.com

$\mathrm{O}$ estilo de vida na contemporaneidade $\mathrm{e}$ a competitividade propiciam às pessoas uma necessidade de deslocamento contínuo, tanto no trabalho como no lazer. Esse dinamismo faz que os indivíduos se distanciem geograficamente de seus lares, locais de trabalho e entes queridos. O poder de mobilidade, a incorporação de novas funcionalidades e a disponibilidade de infraestrutura para suportar o uso dos equipamentos móveis foram alguns fatores que propiciaram a grande aceitação dessa nova tecnologia pela população contemporânea. Essas necessidades, aceitação e apropriação, ocorrem em todas as áreas da sociedade, inclusive no mundo da informação.

Nesse contexto, os pesquisadores João Canavilhas e Ivan Satuf organizaram o livro Jornalismo para dispositivos móveis: produção, distribuição e consumo, uma coletânea de informações fornecidas por diversos pesquisadores, abordando diversas possibilidades de produzir, elaborar e trabalhar com jornalismo para ser acessado por dispositivos móveis.

O primeiro capítulo, "Linguagens e narrativas no jornalismo móvel”, é composto por textos que abordam os formatos de linguagens utilizados nas mídias móveis, as preocupações que o jornalista deve ter para desenvolver um bom trabalho nessa nova tecnologia, e o novo formato de compor o documento. Os autores definem e exploram o termo affordances como sendo nova forma e novo formato de criar conteúdo para smartphones e tablets. Estão incluídos também textos sobre mobilidade e realidade aumentada, hipermídia em revistas digitais móveis e novos modelos de participação da audiência do jornalismo televisivo em dispositivos móveis digitais. Exemplos de narrativas e ilustrações com gravuras e desenhos gráficos complementam esse capítulo, 
dando uma melhor visão das aplicações possíveis no jornalismo para as tecnologias móveis.

Estudos de casos são apresentados e abordados no segundo capítulo, intitulado exatamente "Estudos de casos", dando uma humanização ao conteúdo teórico apresentado no capítulo anterior. São situações variadas, nos mais diversos temas, sendo estes três bem interessantes: "o uso de smartphones na fotografia jornalística" (apresenta fotos tiradas por smartphone que foram capa de revistas), "los desafíos del periodismo móvil en los cibermedios portugueses y españoles" (mostra que a utilização das mídias móveis no jornalismo é um fenômeno global), e "convergência jornalística e a produção de notícias para dispositivos móveis: a experiência dos jornais paraibanos" (aborda a convergência dos vários meios de comunicação, TV aberta e a cabo, rádio, jornal, portal de notícias e portal de esportes).

No terceiro capítulo, "Jornalismo local e televisão em ambiente móvel", os três textos apresentados - "Touch my paper: a imprensa regional na era dos dispositivos móveis", "Mobile devices and APIs in the framing of hyperlocal journalism" e "Mutações da narrativa radiofônica em dispositivos móveis digitais: funcionalidades e potencialidades como determinantes na construção da notícia" - relacionam a televisão com os dispositivos móveis, criando uma nova forma de interação e participação do telespectador que, antes do surgimento das mídias móveis e da internet, ficava na posição de apenas ouvinte, podendo agora expor suas opiniões, críticas e sugestões - em resumo, ser ouvido.

"Inovação e investigação" é o título do quarto capítulo, e nele é abordada a interatividade que os dispositivos móveis e a internet trouxeram ao jornalismo, além das inovações geradas a partir do desenvolvimento tecnológico e da funcionalidade para manipulação das informações pela tela sensível ao toque (touchscreen). No âmbito investigativo, os autores mostram uma pesquisa realizada para avaliar os recursos de interatividade de alguns aplicativos em dispositivos móveis, mostrando que algumas vezes eles não usam os recursos na sua totalidade e apontando ainda que, na maioria das vezes, as pessoas escolhem o dispositivo móvel pelas funcionalidades presentes de interatividade.

O livro Jornalismo para dispositivos móveis: produção, distribuição e consumo aborda de forma completa, em todos os seus capítulos, os assuntos e estudos de casos pertinentes ao tema, trazendo ilustrações, análises e reflexões. Canavilhas e Satuf fazem uma ótima organização dos textos criados por diversos autores, de forma coerente e com uma sequencia lógica, com o cuidado de tratar o assunto no contexto global, inserindo no conteúdo situações e casos de diversos países.

A obra é bastante adequada para a atualidade e em um primeiro momento pode ser considerada como um manual informativo, pois traz informações detalhadas que 
estimulam o leitor a se aprofundar em cada tema apresentado. Em outra oportunidade, pode auxiliar jornalistas seniores, que possuem experiência profissional anterior à cultura digital, a se familiarizarem com as novas tecnologias e as novas formas de fazer jornalismo. Por fim, para os que pretendem ingressar na profissão, traz um conteúdo informativo com subsídio para enriquecer o conhecimento.

CANAVILHAS, J; SATUF, I. (Orgs.). Jornalismo para dispositivos móveis: produção, distribuição e consumo. Covilhã: Labcom, 2015. 496 p. (Coleção Livros LabCom). Disponível em: <http://www. livroslabcom.ubi.pt/pdfs/20150622-201515_jdm_jcanavilhas.pdf >. Acesso em: 10 ago. 2016. 